Faturrachman, Y. \& Sulaiman, D. (2020). How rural instructor implements English for Specific Purposes (ESP): Instructor's perception. Celtic: A Journal of Culture, English Language

Teaching, Literature, \& Linguistics, 7(1), 94-101.

\title{
HOW RURAL INSTRUCTOR IMPLEMENTS ENGLISH FOR SPECIFIC PURPOSES (ESP): INSTRUCTOR'S PERCEPTION
}

\author{
${ }^{1}$ Yani Faturrachman*, ${ }^{1}$ Dady Sulaiman \\ ${ }^{1}$ Universitas Kaltara, Indonesia \\ *Corresponding Author: fatur.yani92@gmail.com
}

\begin{abstract}
Teaching ESP is necessary to be applied by the ESP instructors because one of the teaching ESP requirements is the instructors must prepare the suitable precision of English materials for the ESP students. From several chronological descriptions, the researchers convey that he applies the qualitative study as his approach in the study. Indeed, the three techniques mostly are usually used by the researchers in order to cover the completely problematic statements in this study. The result of data indicated that there were several the fact assumptions that the ESP instructor mostly were always implementing the suitable lesson for teaching which were; (1) doing the needs analysis, (2) setting the instructional goals, (3) selecting the materials, (4) selecting the teaching techniques, (5) preparing the teaching media, (6) doing the teaching activities, and (7) adapting the learning sources. Furthermore, the semi structured interview showed that the ESP instructor has described the chronological problems and solutions when they have designed and implemented lesson plan such as; The problems in selecting the properly real ESP material, in order to solve that the ESP instructor proposed the phenomenal perception that they mostly used the communicative language teaching to encounter the fact problems. Finally, the purpose of this study is to develop the way ESP instructor can evaluate their teaching application and learning process so that he can change their perception in implementing a teaching plan.
\end{abstract}

Keywords: ESP; Perception; Teaching Plan

\begin{abstract}
ABSTRAK
Mengajarkan ESP memerlukan penerapan oleh intruktur ESP karena salah satu syarat pembelajarannya adalah keharusan seorang instruktur mempersiapkan materi yang layak dari pengajaran untuk ESP. Penelitian ini menggunakan deskripsi kualitatif sebagai pendekatan. Dari proses analisa data, diketahui bahwa instruktur ESP selalu menggunakan fakta dan asumsi yang sesuai untuk pengajaran, yaitu; (1) analisis kebutuhan, (2) membuat tujuan pembelajaran, (3) seleksi material, (4) memilih teknik pengajaran (5) menyiapkan media pembelajaran, (6) melakukan pembelajaran, dan (7) mengadaptasi sumber belajar. Selebihnya, wawancara sudah dilakukan dengan menggunakan semi-struktur interview. Selanjutnya, hasil analisa dari data interview menunjukkan bahwa instruktur ESP mampu menjelaskan secara kronologis berbagai masalah serta solusinya saat mereka mendesain dan mengimplementasikan Rencana Pembelajaran ESP. Sebagai contoh, permasalahan yang muncul adalah dalam hal pememilihan materi pengajaran untuk ESP yang dianggap sesuai dengan tujuan pembelajaran. Sebagai solusi, instruktur ESP dalam penelitian ini memilih untuk menggunakan pendekatan pembelajaran bahasa komunikatif yang dianggap mumpuni dan sesuai untuk mengatasi masalah yang tengah dihadapi dalam mengimplementsikan rencana pembelajaran yang telah dibuat. Akhirnya, penelitian ini dilakukan demi merekam dan mengkhasanahkan persepsi instruktur dalam menerapkan pembelajaran ESP sehingga nantinya, diharapkan instruktur mampu merumuskan cara pandang/pikiran dalam mengaplikasikan rencana pengajaran yang efektif bagi pembelajar
\end{abstract}


Celtic: A Journal of Culture, English Language Teaching, Literature and Linguistics

Vol. 7, No. 1, June 2020.

E-ISSN: 2621-9158 P-ISSN:2356-0401

http://ejournal.umm.ac.id/index.php/celtic/index

sehingga akan dihasilkan luaran pembelajaran yang diharapkan, yaitu peningkatan kemampuan Bahasa Inggris pembelajar.

Keywords: ESP; Percepsi; Rencana Pembelajaran

\section{INTRODUCTION}

Globalization era has facilitated English learning. For English language learning courses are divided into two categories, such as: "English for General English (EGP) and English for Specific Purposes (ESP)" (Basturkmen, 2010). English for Specific Purposes (ESP) is a compulsory program that helps the students to encounter the international globalization era in their discipline areas. Furthermore, there are several important features of learning ESP, they are: 1) English language is being an international language, and increasing number of international students studying in the English speaking countries, 2) ESP program that arises faster attainment of linguistics skills and additionally leads to the acquisition of the desired state of knowledge (Jeczelewski, 2016). Therefore, in globalization era, students should have the competent skill of English in order to facilitate them the proficient encounter for future career.

Additionally, English for Specific Purposes courses are usually designed to make the properly communicate with professional skills in performing particular jobrelated functions. So, Chang et al. (2013) argues that there are five ESP courses, such as: 1) business communication, 2) technical writing, 3) journalistic English, and 4) English for medical students, 5) English for nurses (Kaur, 2016). Thus, learning ESP courses are dominant in all educational contexts that adult students usually use to present the communicative English in particular context. So, ESP design is not purely passive skill design but nowadays ESP design needs the practically communicative which relates to particular job.

In teaching ESP, the ESP instructor has responsibilities the specific role for the ESP students. Moreover, the instructor must implement the appropriate ESP lesson for the major or department because the ESP instructors have many roles for teaching ESP. Fiorito (2005) asserts that "the instructors have several roles for teaching ESP, they are: 1) organizing courses, 2) setting the goals and objectives, 3) creating a learning environment, for instance designing and implementing lesson plan in which is effective and efficient activity, and 4) evaluating the students". Hence, some of the ESP instructor roles should know the comprehensive responsibility while the ESP instructor teach ESP course which is appropriate students' department for instances English for Economic Development department, English for Management, and English for Administration Public.

In fact, the ESP instructor is curriculum designer of designing a lesson plan in teaching English for Specific Purposes (ESP) like lesson planner. According to Harmer (2012, p.176), "course outlining and lesson planning are like maps". In contrast, Almabekova (2010) asserts that "the planning for lessons sometimes can be used as reflecting teaching by instructors in English for Specific Purposes". Based on these assertions, the researcher describes that there is contradictory point of view in explanation of designing lesson plan so that the researcher concludes that lesson plan is a guide which is used by the ESP instructors to recognize the specific set of students 
Faturrachman, Y. \& Sulaiman, D. (2020). How rural instructor implements English for Specific Purposes (ESP): Instructor's perception. Celtic: A Journal of Culture, English Language

Teaching, Literature, \& Linguistics, 7(1), 94-101.

during a single class period. Furthermore, lesson plan may improve the way the ESP instructors well recognize in designing and implementing teaching plan. The researchers formulated how instructor implements does and what problems are faced by ESP instructor in teaching plan.

The instructor of ESP conducts the needs analysis for ESP students. The benefits of needs analysis are to investigate the students' capacity in learning ESP material such as students' needs, wants, and lack. Coanca (2013) found the new approach teaching ESP through lesson plan for teaching ESP to students at the faculty of Computer Science for Business Management. There are several procedures to design lesson plan with students' level wants, needs, and lacks they were;

a) The teaching vocabulary objectives such as: (1) Students enable to express the vocabulary on the topic of "information security". (2) Students are able to introduce new vocabularies related to the specific topic namely: (explaining the terms "information security", "software systems", and enable to relate some vocabularies at the same field, such as "defenses strategies", "virus protection"). (3) Students enable to discover and practice new vocabularies through exercises.

b) The teaching grammar objective: Students enable to practice of specific grammar, prepositions, participles, adverbs and conjunctions.

c) The teaching speaking objectives, they were: (1) Students are capable to communicate with the several vocabularies such as, "online security" and "online business situations". (2) Students are capable to discover new vocabulary from the students' presentation in which related to students' major in IT. (3) Students are able to communicate with the instructor-students and students-students with English language.

In fact, lesson plan will be good if the instructors of ESP conducted by starting from the needs analysis, concepts of the objectives and learning goals, teaching methodology, procedures to be taught, and times in the class. These steps, the instructors should be realized as lesson planner in teaching ESP.

(A). A Syllabus

A syllabus is defined broadly as a statement of any part of teachers overall plans converted in a classroom interaction for any part of curriculum. A syllabus enables the students to learn ESP based on the students' major. According to

Furthermore, there were three stages in designing and implementing the ESP syllabus based on the students' needs and wants in higher Education.

(B). the problems are faced by ESP instructor in implementing a teaching Plan

English for Specific Purposes (ESP) is designed to determine the precise material for students' needs, wants, and lacks. In fact, most of the ESP instructors face the problems when they design and implement lesson plan in teaching ESP. Hoa and Mai (2016) found that there were numbers problems that were faced by the ESP instructors.

There are three factors problems that are faced by the ESP instructor namely: (1) the problem is caused by the students' ability, (2) the problem is caused by the ESP instructor does not well-know the specialize knowledge which related to ESP, and (3) problem is caused by an environments conditions. The ESP instructors should recognize the proper material and well-know the specialize knowledge about ESP and analyze 
Celtic: A Journal of Culture, English Language Teaching, Literature and Linguistics

Vol. 7, No. 1, June 2020.

E-ISSN: 2621-9158 P-ISSN:2356-0401

http://ejournal.umm.ac.id/index.php/celtic/index

learning situations. So, teaching plan must follow the appropriate characterization of requirements is specific organization plan in order to help the students the fact goals in their future career. Based on the finding above, there are numbers problems that are faced by the ESP instructor as they feel challenge to make the enabled improvement and increase the ESP theory in decision the suitable lesson plan.

As matters of fact, the most of the problems were faced by the ESP instructors which were; (1) content course selection and (2) the instructor pedagogy competency in teaching ESP. Furthermore, Almabekova (2010) asserts that "the planning for lessons sometimes may be used as reflecting teaching by an instructor in English for Specific Purposes (ESP)". It means lesson plan should be reflected by the ESP instructor. By doing reflection, the ESP instructor will be aware to face problems in designing and implementing lesson plan for teaching ESP. Hence, the ESP instructor needs to investigate the solution in order to improve in the teaching ESP.

\section{METHOD}

In this study, the researcher has used qualitative as an approach to collect the information and data. Leedy and Omrod (2010, p.94) states "qualitative research aims to study the many nuances and complexities of a particular phenomenon". Regarding the theory above, the researcher has collected the comprehensive information through the qualitative study approach. Moreover, the researchers wrote the observation check listed and field noted, and then recorded the classroom activities. The usages of video recorded are one of source the original documentation data during the teaching and learning process. The researchers described and recorded all activities that related to the process of implementing a teaching plan that has done by ESP instructor in three classes. The researchers asked the ESP instructor to give the syllabus and Teaching plan. Documentation may be analyzed. The researchers conducted semi-structured interviews to investigate the way ESP instructor designed a lesson plan and their believed, opinion, and attitude. The benefits of semi structured interview was permitted by the researchers to be investigated through asking anything and in-depth interview in details to the subject or participants (Fraenkle, 2012:446).

The researcher selected the focuses on this study from statements of the study, for instances the process of ESP instructor implemented teaching plan from syllabus/course outline, the problems were faced by them, and the way ESP instructor solved the problems in implementing a lesson plan. Data collection described about the process of implementing a teaching plan from Course outline. In addition, the researcher re-reads the result of field notes, check list and preliminary study to prepare the data based on phenomenon in the classes. Video records replay to begin the process of analysis. The researchers reduced video records to prepare to be analyzed. Besides, the researchers also syntheses the field notes and check list and documents' data to begin the process of analysis.

\section{FINDINGS AND DISCUSSION}

The findings section covers the description of research site, the description of archival documents (lesson plan), and the description of interviews. Thereafter, the discussion described in the findings is the closing statement of the chapter. 
Faturrachman, Y. \& Sulaiman, D. (2020). How rural instructor implements English for Specific Purposes (ESP): Instructor's perception. Celtic: A Journal of Culture, English Language

Teaching, Literature, \& Linguistics, 7(1), 94-101.

\section{The Way ESP instructor implements a Teaching Plan}

Table 1. ESP instructor implements a teaching plan

\begin{tabular}{|c|c|}
\hline The observation study & English for Management \\
\hline Doing Needs Analysis & $\begin{array}{l}\text { The instructor conducts the needs analysis in the first } \\
\text { meeting. }\end{array}$ \\
\hline $\begin{array}{l}\text { The Explaining the goals for } \\
\text { students }\end{array}$ & $\begin{array}{l}\text { In every meeting, the instructor designs the instructional } \\
\text { goal is too general for the students. }\end{array}$ \\
\hline \multirow[t]{5}{*}{ Giving the materials } & $\begin{array}{l}\text { The instructor presents the materials from the syllabus. } \\
\text { Sometimes, he invites them toward the English for } \\
\text { Management. Furthermore, the material adapts from } \\
\text { internet. }\end{array}$ \\
\hline & Bargaining, \\
\hline & How to promote \\
\hline & Product and Company, service \\
\hline & $\begin{array}{l}\text { The way complaining and responding for } \\
\text { costumer/consumer }\end{array}$ \\
\hline $\begin{array}{l}\text { Communication transactional } \\
\text { about Bargaining, } \\
\text { Complaining, and } \\
\text { Responding to consumer, } \\
\text { procedure text. }\end{array}$ & $\begin{array}{l}\text { Students demonstrate the materials "description and } \\
\text { procedure text in promoting product and company". Then, } \\
\text { the instructor divided them to make some groups. }\end{array}$ \\
\hline
\end{tabular}

Based on the findings, the researcher notices that most of them have the standardized procedures to design a lesson plan in teaching ESP. It is in line with Coanca's report (2013) that "instructors conducted the needs analysis in designing and implementing lesson plan such as; learning situation, target situation, creating interesting and appealing materials, establishing general syllabus of the topics and tasks, producing detailed language skills and checking language and skills content of materials".

In short, the ESP instructor should recognize teaching plan in order to better the procedure in implementing a teaching plan. The researchers describe there are two points in this study which are; (1) the process of implementing a teaching plan in determining the course. It is in line with Almabekova's declaration (2010) that "the planning for lessons sometimes can be used as reflecting teaching by the ESP instructors in teaching process". The purpose of this study is to develop the way ESP instructors can evaluate their teaching design and learning process so that they may change their perception in designing and implementing a lesson plan.

\section{The Problems are faced by ESP Instructor in Implementing a Teaching Plan}

During the semi structured interview session, the researchers had conducted the semi structured interview sections on Sept $27^{\text {th }}$ and December $19^{\text {th }}, 2018$ at Kaltara University. The researcher tries to identify that there are two problems that are faced by the ESP instructor when he were implementing a teaching plan. As follows:

(1) The ESP instructor lacked of the theoretical of ESP

In teaching ESP, the knowledge of the theoretical of ESP is the proficiency the instructor to practical the organization in certain way. Based on semi structured interview, ESP instructor has realized to teach the ESP students that the teaching 
Celtic: A Journal of Culture, English Language Teaching, Literature and Linguistics

Vol. 7, No. 1, June 2020.

E-ISSN: 2621-9158 P-ISSN:2356-0401

http://ejournal.umm.ac.id/index.php/celtic/index

vocabulary was the most difficult for the majority of students' ESP, and followed by pronunciation. The amount of unfamiliar vocabulary made students feel worried because most medical terminology is multisyllabic words in which the medical vocabularies are longer and more complicated than the commonly used words.

I think problem is, when students pronounced some vocabularies in

English. ESP students spoke some English words which were

influenced by the first language. (Instructor)

Commonly, most of English for Specific Purposes material is learning vocabulary which is appropriate with students' discipline areas. The result of the data indicates that he has revised their vocabularies and needed much more time in learning process. Therefore, the teaching vocabulary actually is one of the characteristics of learning ESP and the appropriate vocabulary with their field of study such us, the needs, wants, and lacks.

(2) The problems in selecting ESP materials

The characteristic of teaching ESP is determining the eligible material for students' field of study. In this case, most of ESP materials should be revised by ESP instructor when designing a lesson plan. The result of semi structured interview shows that the ESP instructor has faced a problem when she has selected the appropriate material for their discipline areas.

For instance the material is future life which she has taken from syllabus.

I have a problem when I select material from syllabus. I think this

syllabus is not connected with what is being discussed. (Instructor)

The result of the data shows that the ESP material should have specific purposes for their discipline areas. Therefore, the ESP instructor selects the material by adapting other sources otherwise the material is not appropriate with their future career. In teaching ESP, the ESP instructor must investigate the situation and the condition of the ESP students. There are two several feature steps that they conduct to investigate the ESP students in designing and implementing a teaching plan. They are: (1) The ESP instructor asks them to speak up in order to check them the knowledge of the ESP by asking and answering questions. (2) The ESP instructor tries to select the materials from syllabus. Based on the findings descriptions, in short, the researchers indicate the fact that the ESP instructor does the needs analysis for the students' proficiency in learning English. It is similar to Hoa and Mai's report (2016) who report that "there are two issues that happened by ESP instructors which are; (1) the problems relate to students of ESP and (2) the problems relate to the ESP instructor". In this section, the researcher indicates that each ESP instructors encounter the problems which relate to the ESP students in designing and implementing a lesson plan.

In contrast, it is contrary with Hutchinson and Water's theory (1990:55) who states that "there are three categories of needs when conducting needs analysis in language classroom, such as; (1) necessity, (2) wants, and (3) lacks. 
Faturrachman, Y. \& Sulaiman, D. (2020). How rural instructor implements English for Specific Purposes (ESP): Instructor's perception. Celtic: A Journal of Culture, English Language Teaching, Literature, \& Linguistics, 7(1), 94-101.

\section{CONCLUSION}

There were some of the implementations a teaching plan which were conducted by the ESP instructor in teaching ESP. As follows: (1) the needs analysis, (2) the objectives for the ESP students, (3) the ESP materials, (4) the teaching media, (5) the teaching technique, (6) the teaching activities and (7) the learning source. In fact, from the view of the ESP material, most of the ESP materials are suitable materials from the characterization of English for Specific Purposes are to meet specific students' objective with their discipline areas.

The researchers found that there were two problems that were faced by the ESP instructor which were; (1) the nonexistence of the theoretical of English for Specific Purposes (ESP), and (2) the problem in selecting the ESP materials from syllabus. As a matter of fact, from the view of English for Specific Purposes is must be proper instructors which are graduated by master degree in order to meet specific students' discipline areas.

\section{REFERENCES}

Almabekova. O. A. (2010). Refelective Teaching ESP. Journal of Siberian Federal University. Humanities \& Social Sciences 3 (2010 3) 462-475. Siberian Federal University.

Basturkmen, H. (2010). Developing Courses in English for Specific Purposes: Palgrave Mac Millan: University of Auckland. New Zealand.

Bogdan, R. C, and Biklen, S. K. (2013). Qualitative Research Design for Education: an Introduction to Theory and Methods, fifth Edition: USA. Pearson Education, Inc. (p.107-153)

Chang. Y-J. Liu, J-Y. Yang, F-Y. and Sun, Y-C. (2013). Is what I need what I want? Reconceptualising college students' needs in English courses for general and specific/academic purposes. Journal of English for Academic Purposes 271-280. Department of Foreign Languages and Literature, National Tsing Hua University, No. 101., Section 2, Kuang-Fu Road, HsinChu City 300, Taiwan, ROC.

Coanca. M. (2013). New Approach in Teaching ESP. Conference proceedings of eLearning and Software for Education" (eLSE)), issue: 02 / 2013, pages: 464469. Romanian-American University, Bucharest, Romania. accessed on March $27^{\text {th }}$, 2016, at 7.47 p.m.

Creswell, J. W. (2012). Educational Research: Planning, Conducting, and Evaluating Quantitative and Qualitative, 4th Edition: New York. Pearson Education Inc. (p. 212224).

Creswell, J. W. (2014). Research Design: Qualitative, Quantitative, and Mix Methods approaches, Fourth Edition: London. LA. USA: Sage Publication, Inc. (p.234).

Fiorito, L. (2005). Teaching English for Specific Purposes (ESP). ESP Journal. University of Naples.

Fraenkle, J.R, Wallen, N.E, and Hyun, H.H. (2012). How to Design and Evaluate Research in Education, 8th Edition: New York. McGraw-Hill Companies. (p.446).

Hutchinson, T. and Waters, A. (1990). "English for specific purposes", Cambridge University Press.

Harmer, J. (2012). Essential Teacher Knowledge: Core Concepts in English Language Teaching. England and Associated Companies throughout the World. Pearson Education Limited. (P.134-136).

Hoa, N. T. T, and Mai, P. T. T. (2016). Difficulties in Teaching English for Specific Purposes: Empirical Study at Vietnam Universities: Published by Canadian Center of Science and 
Celtic: A Journal of Culture, English Language Teaching, Literature and Linguistics Vol. 7, No. 1, June 2020.

E-ISSN: 2621-9158 P-ISSN:2356-0401 http://ejournal.umm.ac.id/index.php/celtic/index

Education. Higher Education Studies; Vol. 6, No. 2; 2016 ISSN 1925-4741 E-ISSN 1925-475X. Vietnam National University,

Jeczelewski, S. (2016). Needs Analysis, Course Design and Evaluation of Business English B.A. Essay Kt.: 110593-3179. University of Iceland School of Humanities Department of English.

Leedy, and Omrod. (2010). Practical Research Planning and Research: USA. Pearson Education Inc. (p.94).

Maulidiyah, N. (2015). Developing English Material for Library Science students of Terbiyah and teachers training faculty of IAIN Antasari. Thesis Published. IAIN Antasari. Banjarmasin. 